\title{
DVE SLOVENSKÉ INSCENÁCIE VLADIMÍRA MORÁVKA
}

\author{
NADEŽDA LINDOVSKÁ
}

Ústav divadelnej a filmovej vedy Centra vied o umení Slovenskej akadémie vied, Bratislava

\begin{abstract}
Abstrakt: Český režisér Vladimír Morávek vytvoril na Slovensku dve pozoruhodné inscenácie. Obe vznikli na prelome tisícročí a vychádzali zo svetovej divadelnej klasiky. V roku 1999 v Divadle Andreja Bagara Nitra inscenoval Shakespearovho Macbetha a v roku 2005 preniesol na javisko Činohry Slovenského národného divadla v Bratislave Rostandovu hru Cyrano z Bergeracu. Nitriansky Macbeth sa stal najúspešnejšou a najoceňovanejšou inscenáciou divadelnej sezóny 1998/1999. Domáca i zahraničná divadelná kritika vo svojich hodnoteniach nešetrila superlatívmi. Bratislavský Cyrano z Bergeracu patril k divácky vd’ačným repertoárovým titulom, recenzenti však boli voči nemu zdržanlivejší. Obe javiskové diela spájala snaha o originálny výklad známeho dramatického textu, dôraz na herecké výkony, vizualitu, výpravnost̉ a hudobnosṫ. Morávkove réžie Macbetha i Cyrana z Bergeracu obohatili vztahy slovenského a českého divadla o novú skúsenost’ a stali sa významnou súčastou umeleckej biografie viacerých divadelných tvorcov.

Klúčové slová: Vladimír Morávek, slovenské divadlo, inscenovanie klasiky, William Shakespeare: Macbeth, Edmond Rostand: Cyrano z Bergeracu, réžia, Divadlo Andreja Bagara Nitra, Cinohra Slovenského národného divadla
\end{abstract}

\section{Nitriansky Macbeth (1999)}

V čase pozvania do Divadla Andreja Bagara (DAB) bol režisér Vladimír Morávek umeleckým šéfom Klicperovho divadla v Hradci Králové a mal povest' „,divadelného šialenca“. Patril k novej silnej režijnej generácii devät’desiatych rokov, ktorá po roku 1989 s vervou prinášala na javisko nové témy a postupy. Jeho nitrianske hostovanie bolo súčastou ambicióznej stratégie mladého dramaturga Svetozára Sprušanského, ktorý podporoval experiment a postmoderné režijné trendy, nebál sa riskovat’ a vedel presadit’ odvážne projekty. ${ }^{1}$ Usiloval sa umelecky revitalizovat’ súbor aj repertoár DAB tak, aby sa vymanilo z regionálneho rámca, nadviazalo na úspešnú éru Jozefa Bednárika a mohlo konkurovat nielen popredným slovenským, ale aj zahraničným scénam. Do týchto plánov patril zámer inscenovat najkratšiu Shakespearovu tragédiu Macbeth v réžii mladého kontroverzného českého režiséra, ktorý provokáciu a sarkazmus vedel spájat’ s vel'kou dávkou emócií a javiskovej imaginácie.

Morávek sa práve ocitol v Kristových rokoch, pochádzal z národnostne zmiešanej česko-slovenskej rodiny a slovenský pôvod jeho mamy - rodáčky z Oravy - bol

\footnotetext{
${ }^{1}$ Vd’aka úsiliu Svetozára Sprušanského v Divadle Andreja Bagara koncom devätdesiatych rokov 20. storočia a začiatkom 21. storočia hostovali viacerí talentovaní zahraniční režiséri, napr. Jan Antonín Pitínský (1997, ČR), Gintaras Varnas (2000, Litva), Robert Alföldi (2001, Mad’arsko). Ich nitrianske inscenácie odrážali generačné hl'adanie mladého stredoeurópskeho divadla a prekračovali našu regionálnu úroveň.
} 
údajne jedným z dôvodov, prečo prijal pozvanie na Slovensko. Vyštudoval réžiu na Janáčkovej akadémii múzických umení v Brne. Po niekol'koročnom pôsobení v Divadle Husa na provázku² zakotvil v roku 1995 v Hradci Králové. Už zakrátko získalo Klicperovo divadlo pod jeho vedením prestížnu Cenu Alfréda Radoka - Divadlo roku 1998. Mladý divadelník so škandálnou povestou od roku 1993 vel’a spolupracoval s Českou televíziou na tvorbe dokumentárnych filmov. Podobne ako v divadle ho tematicky lákali zvláštne príbehy zaujímavých l’udí, popri slávnych osobnostiach rád venoval pozornost’ menej známym, avšak neopakovatel’ným a nevšedným jedincom.

Svetozár Sprušanský pozorne sledoval novú vlnu českej réžie a aktívne sa zaujímal o Morávkovu tvorbu. Slovenské publikum sa s ňou oboznámilo prostredníctvom Medzinárodného festivalu Divadelná Nitra, na ktorom uviedli tri Morávkove inscenácie, $\mathrm{z}$ toho $\mathrm{v}$ dvoch prípadoch išlo o netradičné interpretácie českej klasiky. ${ }^{3}$ V roku 1997 po sérii naštudovaní súčasnej českej drámy sa Vladimír Morávek pustil do realizácie cyklu nazvaného Boh ochraňuj Williama Shakespeara. Pôvodne neuvažoval inscenovat' na Slovensku Macbetha, ale Král'a Leara, napokon rozhodnutie zmenil. ${ }^{4}$

V Nitre sa stretol s mimoriadne motivovaným a disciplinovaným kolektívom - hereckým aj technickým, oddaným divadelnej práci nad rámec pracovnej doby, ochotným experimentovat’ a akceptovat’ rozmanité nároky originálneho tvorcu. Slovenské herectvo ho lákalo svojou zvláštnou silou, ktorú obrazne prirovnával k vysoko výkonným motocyklovým motorom. ${ }^{5} \mathrm{~V}$ DAB však chýbal herec schopný naplnit’ režisérovu predstavu o hlavnej postave. Preto si vyžiadal jedného z protagonistov Slovenského národného divadla Mariána Labudu a ten riskantnú ponuku na účinkovanie vo vidieckom divadle prijal. Morávek si so sebou priviedol českého hudobného skladatel’a Daniela Fikejza, scénu a kostýmy zveril slovenskej javiskovej výtvarníčke Alexandre Gruskovej. V oboch prípadoch išlo o vel'mi štastné rozhodnutie, s oboma už predtým úspešne spolupracoval. Grusková navyše v devät’desiatych rokoch patrila k okruhu stálych spolupracovníkov DAB, výborne poznala súbor a technické možnosti scény, považovanej za najväčšiu v bývalom Československu. V ústretovej nitrianskej atmosfére sa zrodila inscenácia, ktorá sa stala hlavnou udalostou slovenskej divadelnej sezóny 1998/1999 (premiéra 27. 3. 1999), posilnila umelecké renomé Vladimíra Morávka aj DAB a zaradila sa do zlatého fondu slovenského divadla.

Interpretácia tzv. škótskej tragédie sa niesla v intenciách, ktoré ešte v šest’desiatych rokoch 20. storočia nastolil pol'ský divadelný kritik a teoretik Jan Kott - vychádzala z princípu aktualizácie, z prepojenia starého divadelného príbehu s dneškom. Výsledok fascinoval svojou netradičnostou, bohatou fantáziou a vel'kolepou spektakulárnostou. Inscenátori prostredníctvom symbiózy všetkých dostupných javiskových prostriedkov podporili Morávkov východiskový koncept. Režisér "nadstavil“ text

${ }^{2}$ V Divadle Husa na provázku (DHNP) v Brne pôsobil Vladimír Morávek v rokoch 1989 - 1995. Začínal v Detskom štúdiu DHNP. Hladanie svojského režijného rukopisu vyvrcholilo inscenáciou Mariša (1995). V roku 2005 sa do DHNP opätovne vrátil a dvanást rokov ho viedol už ako umelecký šéf.

${ }^{3}$ Festival Divadelná Nitra 1992, 1995, 1996 z ranných réžií Vladimíra Morávka uviedol inscenácie Sny (Nedětské studio DHNP), Mariša (bratia Mrštíkovci, DHNP) a Jej jej pastorkyňa (Gabriela Preissová, Klicperovo divadlo).

${ }^{4}$ Shakespearovho Král’a Leara Morávek inscenoval v Klicperovom divadle (1998).

${ }^{5}$ Pozri MORÁVEK, V. - SPRUŠANSKÝ, S. Morávek o divadle. [Rozhovor]. In William Shakespeare: Macbeth [Bulletin k inscenácii]. Nitra : Divadlo Andreja Bagara, 1999, nečíslované. 


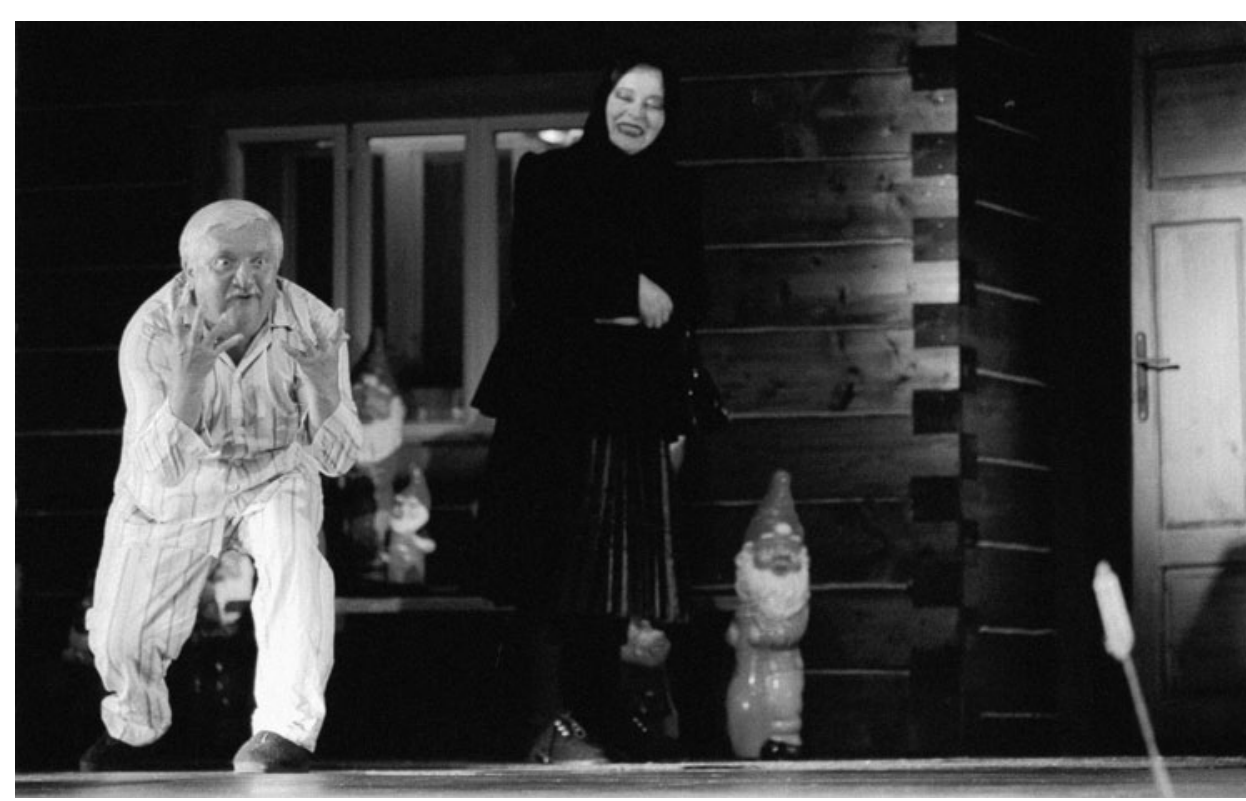

William Shakespeare: Macbeth. Divadlo Andreja Bagara Nitra, premiéra 27. 3. 1999. Réžia Vladimír Morávek. Marián Labuda (Macbeth), Hilda Augustovičová (Druhá bosorka). Foto archív DAB. Snímka Ctibor Bachratý.

o metapríbeh nášho súčasníka a cez neho analyzoval zrod zla v človeku bažiacom po moci. Tragédiu, čo „sa rodí z temnôt l’udského srdca“", tlmočil ako vitálny a večne sa opakujúci archetypálny príbeh, ktorý sa môže rozvinút kdekol'vek a kedykolvek.

Labudov Macbeth bol všedným, pupkatým dedinčanom z konca 20. storočia, obklopeným nevkusom, hlinenými trpaslíkmi a manželskou nudou zriedenou sledovaním hrdinských vel'kofilmov. Vd’aka divadelnej mágii jednej noci vstúpil do reality televíznej obrazovky, z vidieckej všednosti sa preniesol do sveta alžbetínskej tragédie. Ihned' sa tam zabýval a začal aktívne žit krvavý sen o moci. Vyzeral však ako protiklad tradičnej predstavy tragického hrdinu. V podaní Mariána Labudu nadobudol Macbeth grotesknú podobu, prichádzal na javisko v pyžamku a zotrval v ňom temer do polovice predstavenia. Svojím vzrastom a telesnou konštitúciou pripomínal trpaslíka, avšak zbaveného dobrosrdečnosti. Po prekonaní počiatočnej plachosti získaval jeho antihrdina čoraz väčšie sebavedomie a s gestom führera vyrážal na cestu za královskou korunou. Z malého dedinčana vyrastal na spupného diktátora, pyžamo vymenil za károvaný kilt a zlatom zdobený odev. Stával sa vrahom a tyranom, schopným zabit’ vlastnú ženu. V Morávkovej interpretácii to bol totiž on, kto zbavil života Lady Macbeth. Rovnako ako v Shakespearovej pôvodine, aj na javisku DAB ho napokon čakal pád a tvrdá odplata. Vo finále sa na javisku objavili bledé prízraky obetí Macbethovej tyranie. Ich ležiace telá postupne zaplnili proscénium, každý mal v ruke bielu laliu. Vznikol obraz cintorína, varujúci pred ničivou túžbou po moci,

${ }^{6}$ HILSKÝ, M. Shakespeare a jeviště svět. Praha : Academia, 2010, s. 635. 


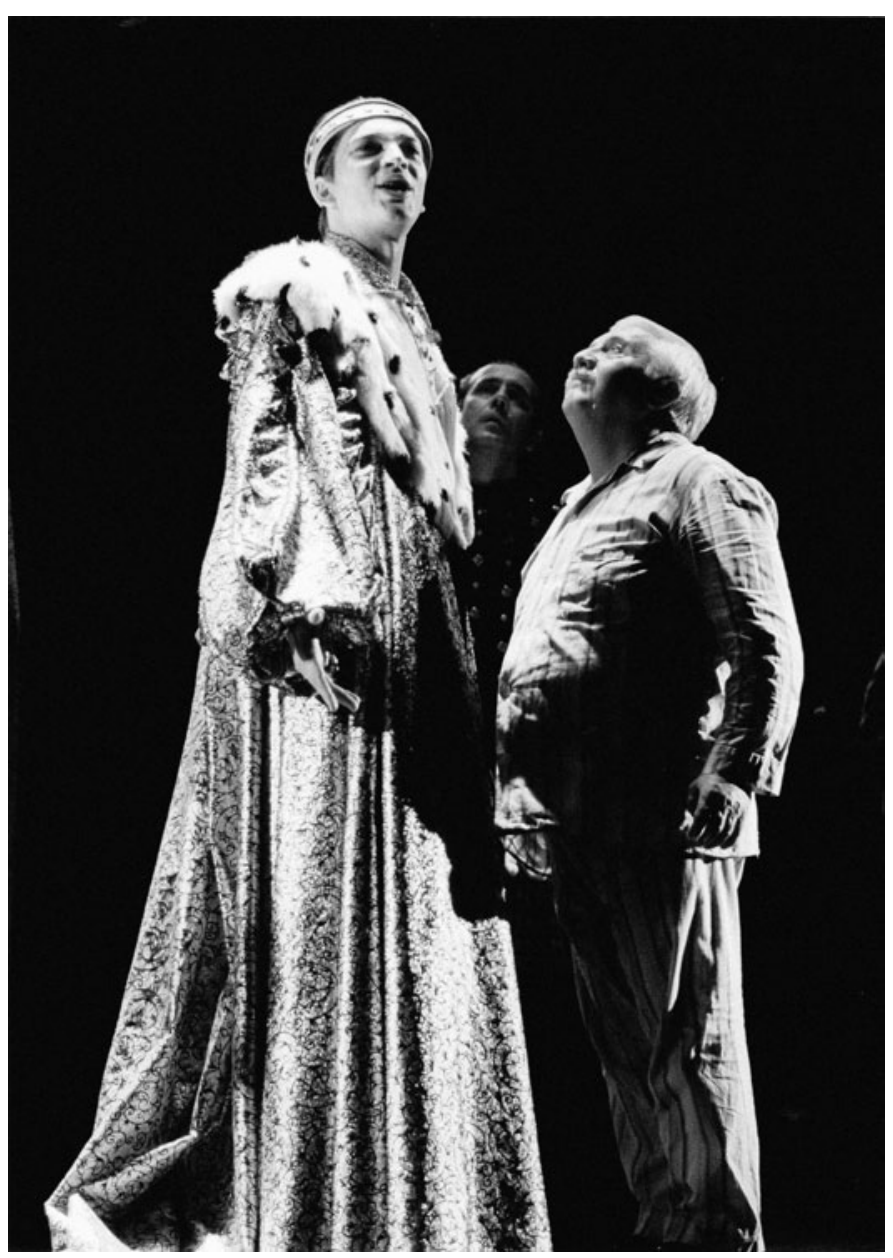

William Shakespeare:

Macbeth. Divadlo Andreja

Bagara Nitra, premiéra

27. 3. 1999. Réžia Vladimír

Morávek. Marek Majeský

(Duncan), Marián Labuda

(Macbeth).

Foto archív DAB.

Snímka Ctibor Bachratý.

ktorá dokáže driemat’ aj v tom najmenšom, najbezvýznamnejšom, najprovinčnejšom človeku.

Inscenácia, v ktorej Morávek zúročil predchádzajúce divadelné i televízne skúsenosti, smerovala od grotesky k vznešenému dramatickému finále. Publikum bolo atakované množstvom imaginatívnych výjavov, symbolov, zvukov a farieb. Aj ked' jeho nitrianska réžia vyznievala extravagantne, nespreneverila sa autorovi a naplnila pre režiséra dôležité krédo všeobecnej zrozumitel'nosti. Ako konštatoval vo svojej recenzii Ladislav Čavojský, bol to „Shakespeare pre začiatočníkov aj pokročilých, pre znalcov najväčšieho svetového dramatika, aj tých, ktorí o ňom nevedia ani ,ň‘. Najprv šokujúca, potom odvážne drzá aktualizácia klasika. ${ }^{\text {"7 }}$

Morávek vytvoril do detailov premyslenú vel'kolepú a dynamickú divadelnú fresku s množstvom postáv a symbolov, s presnou kompozíciou a zložitou štruktú-

${ }^{7}$ ČAVOJSKÝ, L. Príbeh, prerozprávaný kreténom. In Literárny týždenník, 1999, roč. 12., č. 25, s. 11. 
rou. Diváci aj odborníci ocenili, že išlo o divadlo nesmierne pútavé, naplnené človečinou a vd’aka scéne a kostýmom Alexandry Gruskovej esteticky rafinované. Obsahovalo gejzír nápadov a uhrančivú krásu javiskového bytia ozvučenú hudbou, šumom a hlasmi doliehajúcimi akoby z dial'avy neviditelných bojísk. Využili sa všetky technické vymoženosti mimoriadne rozl'ahlej nitrianskej scény - točňa, prepadliská, hydraulika umožňujúca nadvihnút niektoré plochy, divadelný dym a efektné svietenie, dokonca aj sviatočná opona s vel'komoravským motívom. V inscenácii účinkoval temer celý súbor doplnený o štatistov. Podla slov Alexandry Gruskovej, tvorcovia cielavedome vytvárali kontrast dvoch svetov: výnimočného so všedným, vysokého s nízkym. „Chceli sme, aby predstavenie malo intímny rozmer drámy malého človiečika a zároveň aby to bolo monumentálne, vel'kolepé." ${ }^{8}$

Shakespearovho Macbetha v Nitre predstavili v preklade Jozefa Kota. Inscenátori hru upravili, text skrátili, prekomponovali repliky niektorých postáv, preškrtali viaceré lyrické a reflexívne pasáže - ich zlostný Macbeth nemal zmysel pre poéziu a jemnocit. Podaktoré postavy vynechali, iné zase priviedli na javisko (Cawdor, biskup), pozmenili niektoré dejové zvraty (napr. eliminovali samovraždu Lady Macbeth, omladili krála Duncana a namiesto synov mu prisúdili mladších bratov). Básnickú vel'kolepost' Shakespearovho slova a divadelných metafor sa tvorcovia usilovali vyjadrił vizuálne. Z krátkej zmienky o Macbethovej korunovácii stvorili ucelený a vizuálne pôsobivý javiskový obraz. Morávkovi sa podarilo sled živých obrazov postupne gradovat’ a využit ich na rozprávanie príbehu. Jednotlivé postavy aj javiskové dianie ako celok prechádzali premysleným vývojovým oblúkom, motívy sa vrstvili a vzájomne podporovali, až sa vystupňovali k vel'kému finále.

Režijný koncept výrazne podporila atmosférotvorná Fikejzova hudba a Gruskovej scénická výprava. V prvej časti inscenácie dominovala slovenská chalúpka súdobého manželského páru, použitie točne umožnilo vnímat’ dianie v exteriéri (pred domčekom) aj v interiéri. Sem akoby cez televíznu obrazovku vstupovali aktéri škótskej tragédie, manželia ich nasledovali v prospech novej reality a úplne nového životného príbehu. Druhá polovica, v ktorej dedinský manželský pár prijal „macbethovskú" identitu a následne sa zradou a vraždením prebíjal k moci, sa niesla v znamení „krvavočervenej farby v podobe monumentálnych horizontov“. ${ }^{9}$ Elegický záver, pripomínajúci početné obete Macbethových ambícií a zavŕšený modlitbou za pokojnú a štastnú budúcnost’ krajiny, sa odohrával na pozadí bieleho širokouhlého plátna. Efektné monochromatické pozadie v oboch prípadoch vyvolávalo silný emocionálny účinok, zvýrazňovalo siluety postáv a eleganciu jednotlivých mizanscén. Kostýmy boli inšpirované súčasnostou, folklórom aj rôznymi historickými epochami, ale nepôsobili nesúrodo, naopak - esteticky celistvo. Celkové vizuálne riešenie sa rodilo z jednoty režijného zámeru s hereckou akciou, funkčnou scénou, nádhernými kostýmami, hrou svetla a tieňov.

Výtvarná rovina sa rovnocenne prepájala s akustickou. Vd’aka Danielovi Fikejzovi jednotlivé motivické línie nadobudli svojrázny hudobný výraz, preto shakespearista Milan Lukeš oprávnene písal o inscenácii ako o pastve pre oči aj pre uši. ${ }^{10}$ Ján Jabor-

${ }^{8}$ GRUSKOVÁ, A. - JANCUROVÁ, H. Obliekanie ilúzií. [Rozhovor]. In Pravda, 1999, č. 125, roč. 9, s. 11, 18. 5.1999

${ }^{9}$ Tamže.

${ }^{10}$ LUKEŠ, M. Macbeth z domčeku. In Svět a divadlo, 2000, roč. 11, č. 3, s. 8. 


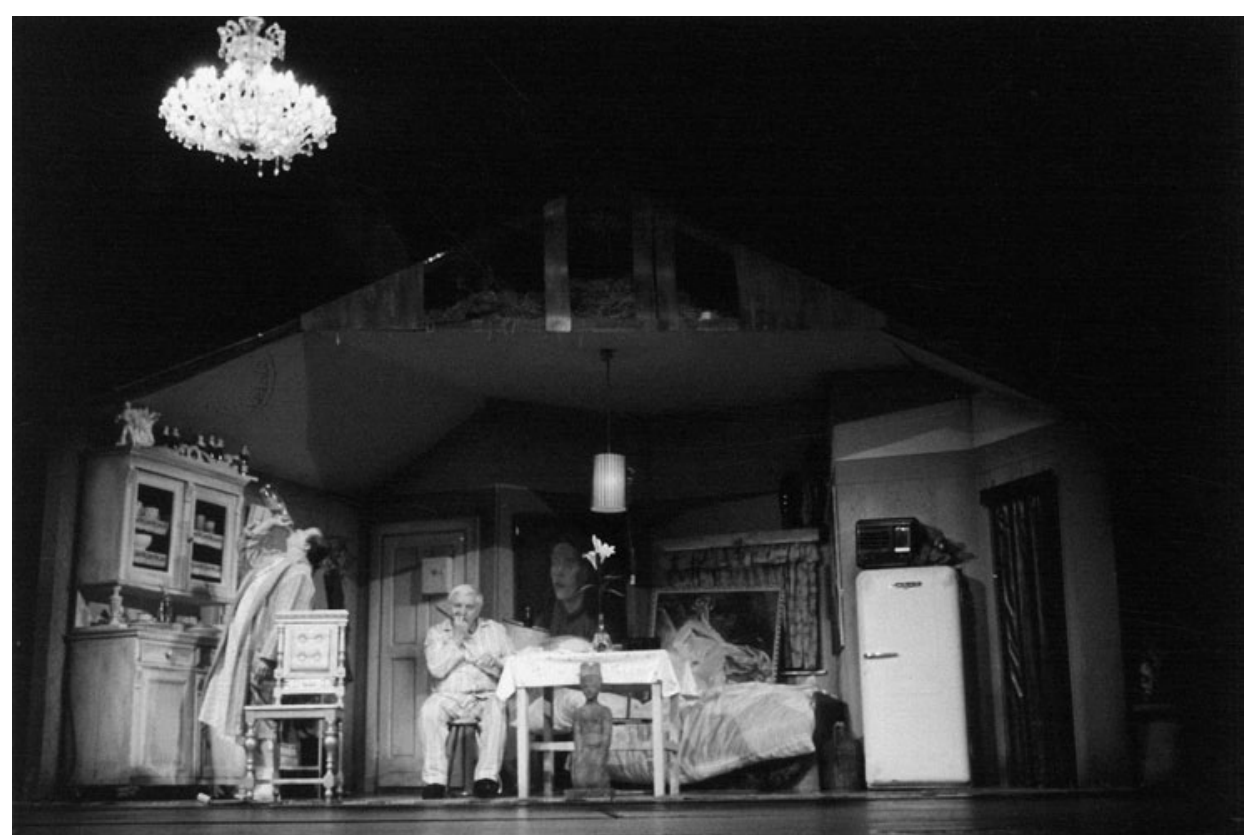

William Shakespeare: Macbeth. Divadlo Andreja Bagara Nitra, premiéra 27. 3. 1999. Réžia Vladimír Morávek. Marián Labuda (Macbeth). Foto Archív Divadelného ústavu. Snímka Ctibor Bachratý.

ník obdivne vyzdvihol bohatú škálu rytmicko-melodických sekvencií, využívaných jednak v predeloch medzi obrazmi, jednak sprevádzajúcich dej: „ (...) tvrdé ostinato (...) pripomína hrozivý postup a završovanie negatívne motivovaného konania (...), postupne sa však rozrastá o hudbu fanfárového charakteru (sprítomňuje Duncana, král’ovský dvor, ale aj atmosféru korunovácie), pochod škótskych gájd (...), o vokál (scéna veštenia), glisandové zvuky pripomínajúce napríklad aj zlovestný let vojnových striel." ${ }^{11}$ Jaborník zaregistroval aj ironické a groteskné tóny a v kontraste k nim „melodicky bohatší, jemne lyricky rozpracovaný motív chvejúcej sa, úprimnej, ohrozovanej a bezbrannej l'udskosti (...) a napokon harfový motív v apelatívnom závere (...). Do zvukového scenára Vladimír Morávek zaradil aj viaceré hovorené citácie od televíznej reklamy cez pripomienky slepého davového ,hajlovania' až po vecné opakovanie hesiel vyslovovaných vo vypätých a vzrušených scénach. " ${ }^{12}$

Popri slovenskej chalúpke a pupkatom Macbethovi v pyžame sa emblematickým pre inscenáciu stalo prekvapujúce stvárnenie tria shakespearovských bosoriek. Ich prítomnost̉ už v úvode predznamenala charakteristickú vlastnost’ nitrianskeho naštudovania Macbetha, a síce neustále prestupovanie reálneho, zvyčajného, známeho s fantaskným, zvláštnym, snovým, teatrálnym. Vedmy vstupovali na javisko ako tri typicky slovenské dedinské ženičky, oblečené do čierneho od hlavy po päty. Pri ohníku pred chalúpkou si opekali špekáčiky a pospevovali l'udovky. Vo svojich hrubých

\footnotetext{
${ }^{11}$ JABORNÍK, J. Ó, Škótsko, Škótsko II. In Divadlo v medzičase, 1999, roč. 4, č. 3 - 4, s. 6.

12 Tamže.
} 
William Shakespeare: Macbeth. Divadlo Andreja Bagara Nitra, premiéra 27. 3. 1999. Réžia Vladimír Morávek. Dušan Lenci (Biskup), Marián Labuda (Macbeth). Foto archív DAB. Snímka Ctibor Bachratý.

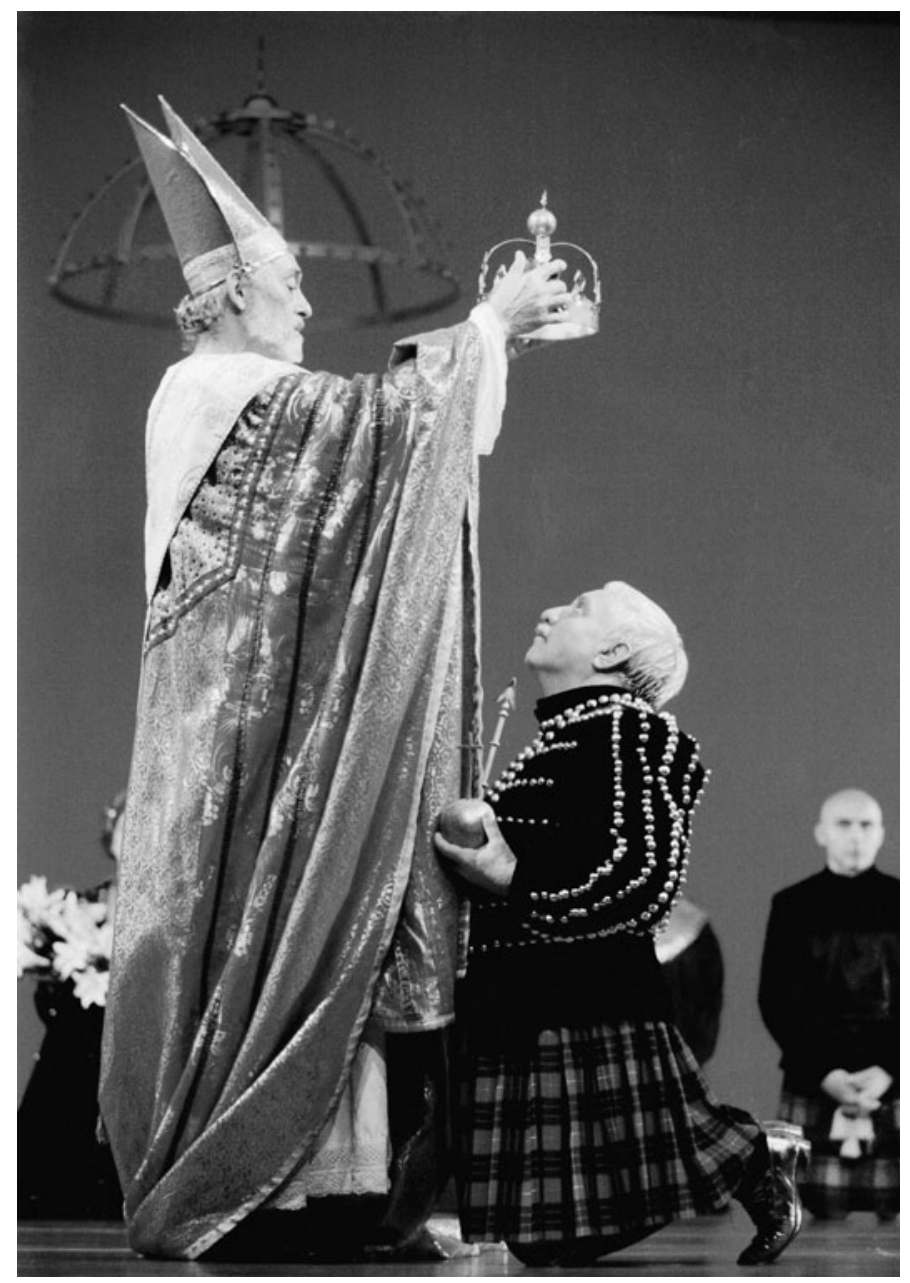

pančuchách, šnurovacích topánkach, čiernych sakách a bohato riasených sukniach boli zlovestne elegantné a uhrančivo temné. Neskôr vysvitalo, že ide o kentaurie ženy - tri hrdé a zlomysel’né čarodejnice, v ktorých sa ludské spája so zvieracím. Tešili sa z každého krviprelievania, prechádzali celým dejom ako emanácia zla, ich veštba spustila Macbethovu premenu na tyrana. Ku koncu škodoradostne naznačovali, že kolotoč vraždenia a boja o moc môže pokračovat'. Ako uviedol Jaborník, „Herečky mimoriadne citlivo pracovali s takmer detailnou štylizáciou a rytmizáciou chôdze, prácou rúk, gest, mimiky“, pritom sa nezriekli špecifickej individualizácie každej z trojice kentaurích žien. ${ }^{13}$

Inscenátori neváhali skĺbit’ slovenské vidiecke, ba až rozprávkovo-folklórne motívy (čarodejnice) s odkazmi na škótsky naturel hry. Zdôraznili, že dej tragédie sa

${ }^{13}$ Tamže. 
odohráva v Škótsku, mužov obliekli do károvaných sukní a (na rozdiel od autora) od začiatku do konca nechali refrénovito zniet povzdych: „Ó, Škótsko, Škótsko!“. Pritom však publiku naznačili, že nitrianske Škótsko je v istom zmysle bájna krajina, ktorá sa dá vnímat’ ako divadelná metafora Slovenska. Zdôraznili to aj použitím slávnostnej nitrianskej opony s vel'komoravskou tematikou, aj slovenským dvojkrížom na zlatých korunovačných insígniách. Svätoplukovská opona zadávala inscenácii tón, otvárala ju a zároveň slúžila ako bodka za záverečnou modlitbou za blaho „Škótska“. ${ }^{14}$ Nádej na lepšiu budúcnost’ znela ako paralela k súdobej situácii Slovenska, ktoré sa spamätávalo nielen z červenej minulosti, ale aj z niekol'kých rokov bezohladnej vlády domáceho politika macbethovského razenia. Záverečnú emóciu ale podfarbovali tiene pochybností: režisér do svojho opusu pridal tragickú tému diet’ata a poškvrnenej nevinnosti. Úlohu porazit’ tyrana zveril malému chlapcovi, následníkovi trónu Donalbainovi (d’alší posun oproti pôvodine), ktorý Macbetha síce vyháňa, ale fyzicky nelikviduje. Na konci dvorania vysadili chlapca skrvaveného v bojoch na zlatý trón. Bolo evidentné, že panovník, ktorého detstvo bolo otrávené nenávistou, krvou a vraždením, bude aj so svojou krajinou odsúdený na d’alšie neštastia.

Inscenácia priniesla sériu vyvážených hereckých výkonov. Ako konštatoval Ján Jaborník, režisér Morávek, odchovanec brnianskej divadelnej školy, viedol nitriansky súbor od zaužívanej dominantnej citovej sugescie $\mathrm{k}$ analytickejšiemu prístupu k tvorbe, $\mathrm{k}$ istému odstupu na spôsob Brechtovho scudzovacieho efektu. ${ }^{15}$ Najviac zažiarili predstavitelia manželov Macbethovcov, ktorí nekonvenčnému výkladu vdýchli život.

Lady Macbeth v podaní kmeňovej herečky DAB Adely Gáborovej bola vulgárna aj dojemná, krutá aj zranitelná, prechádzala viacerými premenami. Táto starnúca, zanedbaná dedinská žena mala zjavný sklon k alkoholu. Podobne ako jej manžel vstupovala do macbethovského mýtu v negližé, presnejšie v obnosenej flanelovej nočnej košeli a v teplých ponožkách. Gáborovej výkon bol bohatý na významové kontrasty a nuansy. V prvej časti inscenácie pani Macbethová pôsobila dojmom úbohej až smiešnej plebejky. Neustále naprávala spoločenské faux pas svojho manžela, v súkromí ho ale nabádala ku král'ovražde. V úvode druhej časti - na korunovácii - sa prezentovala ako honosná matróna, pávica s náručou plnou bielych lalií. V Morávkovej interpretácii tieto kvety veštili smrt'. Pod t’archou výčitiek svedomia Lady Macbeth neskôr vystúpila z roly královnej, vrátila sa k svojej podstate a k svojej nočnej košiel'ke. Jej blúznivé reči o spáchaných zločinoch sa stali hrozbou, a tak ju manžel osobne odstránil zo svojho mocenského sna - za pomoci vankúša.

Hlavnú t’archu režijnej koncepcie niesol Labudov Macbeth. Zosobňoval zakomplexovaného priemerného jedinca, ktorého skrytá túžba po moci za istých okolností môže priviest’ na vrchol mocenskej pyramídy a spôsobit’ svetu skutočnú skazu. Jeho hrdina bol vždy trochu nadurdený a nespokojný, pokrytecký, prefíkaný, zákerný. Herec predviedol suverénny výkon, ale podla slovenskej divadelnej kritiky neprekročil známe polohy svojho umenia. V konečnom výsledku si Divadelné ocenenie sezóny - DOSKY 1999 za najlepší herecký výkon odniesla iba Adela Gáborová. Paradoxne, česká divadelná kritika naopak mimoriadne vyzdvihla predovšetkým

${ }^{14}$ Ako upozornil Ján Jaborník, text záverečnej modlitby bol čiastočne prebraný z tragédie Richard III. Pozri JABORNÍK, J. Ó, Škótsko, Škótsko I. In Divadlo v medzičase, 1999, roč. 4, č. 2, s. 7.

${ }^{15}$ Pozri JABORNÍK, J. Ó, Škótsko, Škótsko II. 
William Shakespeare: Macbeth. Divadlo Andreja Bagara Nitra, premiéra 27. 3. 1999. Réžia Vladimír Morávek. Adela Gáborová (Lady Macbeth), Marián Labuda (Macbeth). Foto archív DAB. Snímka Ctibor Bachratý.

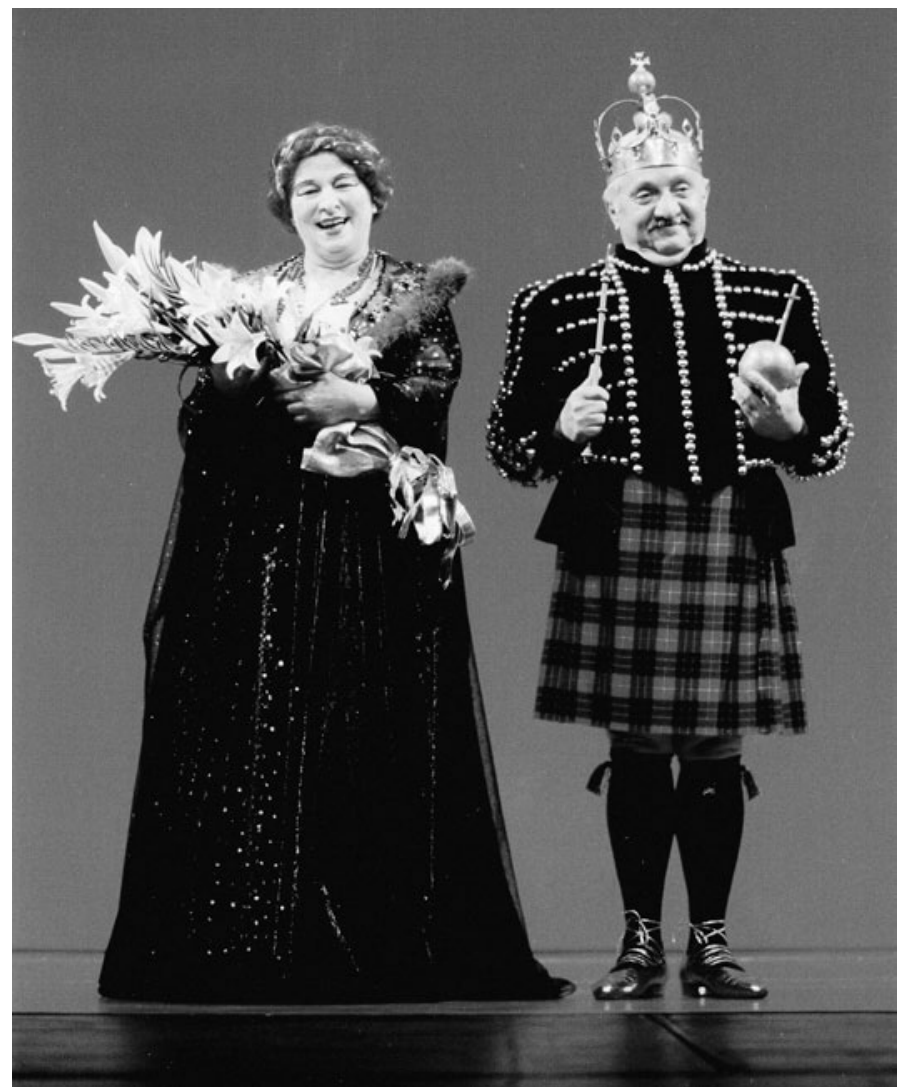

Labudovu kreáciu. Napríklad rozsiahla analýza inscenácie od Milana Lukeša Macbeth $z$ domčeka sa sústredila na pozitíva stvárnenia ústrednej postavy. Podla Lukeša spočíval hlavný vklad Mariána Labudu do Morávkovej „snovej grotesky“ v tom, že svojou javiskovou existenciou a inteligenciou herecky verifikoval proces premeny všedného človiečika na diktátora. Kritik bol presvedčený, že herec Labudovho typu a inteligencie „Macbetha nielen hrat' môže, ale dokonca musí, ak sa má upozornit,, že macbethovský typus nie je kategóriou historickou a elitnou, ale v súčasnom demokratickom svete sa otvára vskutku širokej verejnosti. ${ }^{\text {} 16}$

Pri sumarizácii výsledkov divadelnej sezóny 1998/1999 Divadlo Andreja Bagara so svojím Macbethom triumfovalo vo viacerých kategóriách. Popri spomenutom ocenení za najlepší ženský herecký výkon získala d’alšiu cenu DOSKY výtvarníčka Alexandra Grusková za najlepšiu scénografiu. Samostatná cena za najlepšiu inscenáciu roka sa ušla celému tvorivému kolektívu. Vladimíra Morávka slovenská kritická obec vyznamenala ocenením za najlepšiu réžiu. Triumf pokračoval prostredníctvom úspešnej účasti na medzinárodných divadelných festivaloch v Českej republike, Pol’sku, Vel'kej Británii. Nitriansky Macbeth inšpiroval viacerých divadelných recenzentov a teat-

${ }^{16}$ LUKEŠ, M. Macbeth z domčeku, s. 15. 
rológov k napísaniu väčších i menších analýz. Obdiv k danému divadelnému dielu a ku kolektívnemu výkonu všetkých zúčastnených prevládol naprieč generáciami: napriek Morávkovej povesti „divadelného šialenca“ sa v rámci spolupráce s DAB žiadne vel'ké škandály nekonali.

\section{Bratislavský Cyrano z Bergeracu (2005)}

Strojcom druhého pozvania Vladimíra Morávka na Slovensko bol významný divadelný dramaturg Martin Porubjak. Ponuka tentoraz prišla z Činohry Slovenského národného divadla. V rámci sezóny 2004/2005 tam český režisér pohostinsky naštudoval slávnu veršovanú hru Edmonda Rostanda Cyrano z Bergeracu (premiéra 22. 1. 2005). Pred príchodom do Bratislavy si stanovil jednu zásadnú podmienku: do úlohy Cyrana si vyžiadal režírujúceho herca Martina Hubu. K spolupráci prizval osvedčených spolutvorcov Alexandru Gruskovú a Daniela Fikejza. Prostredníctvom médií Bratislavčanom slúbil, že svojou novou inscenáciou vyrazí v meste poistky. ${ }^{17}$

Vysoké sebavedomie Vladimíra Morávka vyplývalo zo série vel'kých tvorivých úspechov a množstva ocenení, ktoré získal v rozpätí rokov 1998 - 2005. Morávkovo umelecké renomé výrazne vzrástlo. Klicperovo divadlo pod jeho vedením štyrikrát získalo Cenu Alfréda Radoka - Divadlo roku (1998, 1999, 2001, 2003). Celovečerný filmový debut Nuda v Brně mu priniesol viacnásobného Českého leva za najlepší scenár, réžiu a hlavne za film roku 2003. Vydavatel'stvo Pražská scéna venovalo Morávkovej tvorbe samostatnú knižnú publikáciu (2004). ${ }^{18}$ Vymenované pocty tvoria len čast’ z ovel'a väčšieho počtu prejavov uznania, ktoré dosiahol v rokoch medzi dvoma slovenskými réžiami. Režisér prinášal na javisko uragán energie, originálne a provokatívne interpretácie, šokujúce dramaturgické a inscenačné postupy, objavil viacero nových divadelných talentov. České divadlo obohatil o cyklus nekonvenčných tematizovaných viacdielnych projektov vychádzajúcich zo súčasnej drámy, divadelnej klasiky aj prózy a nachádzal sa vo vynikajúcej tvorivej kondícii.

Druhé slovenské host’ovanie Vladimíra Morávka sa od prvého výrazne líšilo. Už to nebol nádejný začínajúci režisér, ale renomovaný tvorca. Neprichádzal do kvalitného vidieckeho divadla, ale do divadla hereckých legiend v hlavnom meste. Vybral si síce klasiku, ale nie shakespearovskú či čechovovskú, s ktorými nadobudol dobré skúsenosti, ale hru nachádzajúcu sa akoby mimo jeho tematických línií. Nespolupracoval už s generačne spriazneným mladým dramaturgom. Martin Porubjak podobne ako predstavitelia Macbetha Marián Labuda a Cyrana Martin Huba patril k slávnemu pokoleniu Divadla na korze z prelomu šest’desiatych a sedemdesiatych rokov. Oproti rozl'ahlému, vzdušnému nitrianskemu javisku a hl'adisku boli scéna a priestory Divadla Pavla Országha Hviezdoslava o niečo menšie. Stačili však na to, aby Morávek pokračoval v koncepte vel'kého výpravného diela s vel'korysými, živými javiskovými obrazmi. Podla svedectva Alexandry Gruskovej režisér chcel, aby

${ }^{17}$ Pozri MORÁVEK, V. - JENČíKOVÁ, M. V Bratislave chcem vyrazit poistky. Režisér Vladimír Morávek hádže po hercoch v národných divadlách avantgardou. [Rozhovor]. In Pravda, roč. 15, č. 17, príloha Sobota, s. I, IV, 22. 1. 2005.

${ }^{18}$ NĚMEČKOVÁ, L. - HULEC, V. - TICHÝ, Z. A. a kol. Vladimír Morávek. U nás nudou neumřete. (Ed. J. Dvořák). Praha : Pražská scéna, 2004. 


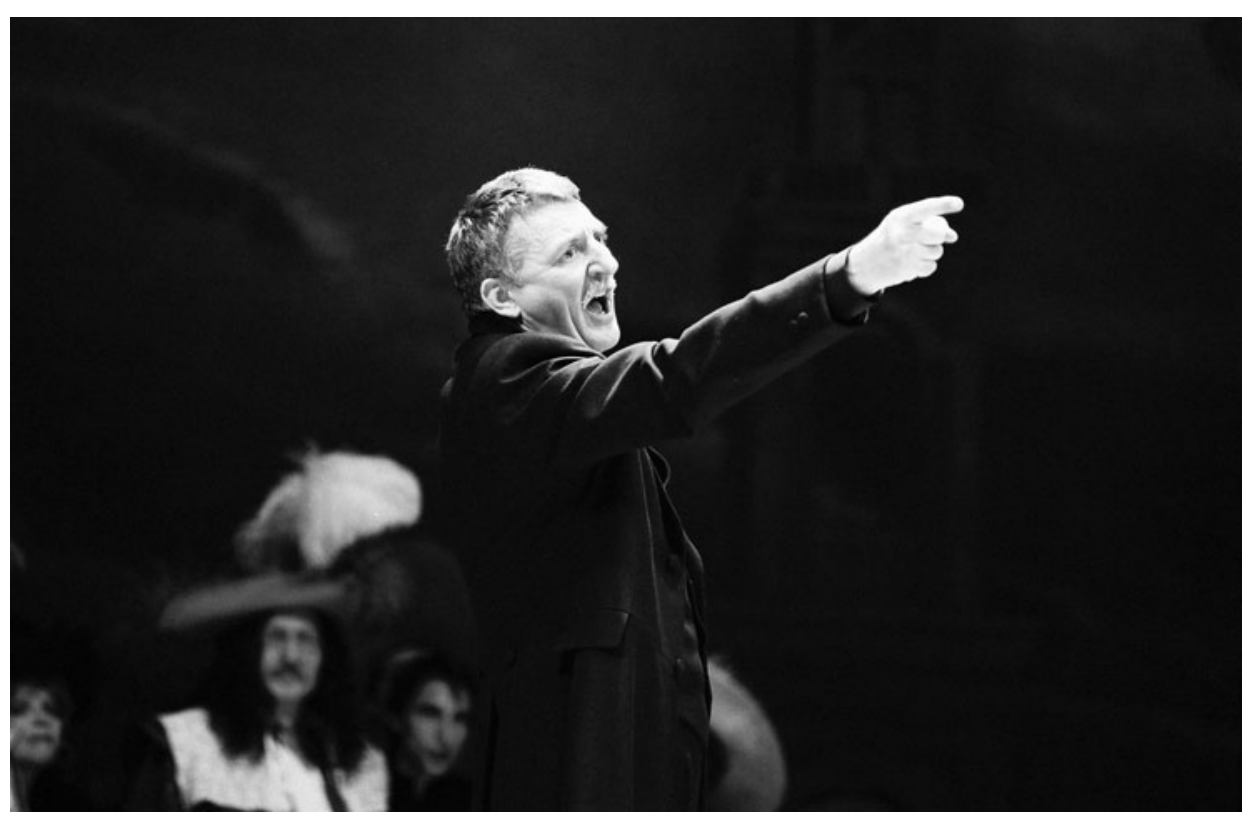

Edmond Rostand: Cyrano z Bergeracu. Činohra Slovenského národného divadla, premiéra 22. 1. 2005. Réžia Vladimír Morávek. Martin Huba (Cyrano). Foto archív SND. Snímka Jana Nemčoková.

tu v plnom nasadení zaznela „sila niekol'kých hereckých generácií“. ${ }^{19}$ Do inscenácie obsadil temer celý súbor, doplnil ho o niekol'kých hostujúcich mladých hercov a najmä o členov chlapčenského speváckeho zboru ${ }^{20}$. Herci zvučných mien stvárňovali epizodické roly, v niektorých chvílach boli na javisku desiatky účinkujúcich, ktorých Morávek nebojácne komponoval do vizuálne elegantných mizanscén.

Bratislavské publikum malo ešte v čerstvej pamäti úspešné naštudovanie Cyra$n a \mathrm{v}$ réžii Romana Poláka s Milanom Lasicom v titulnej úlohe, derniéra tejto verzie sa konala iba pred pár mesiacmi. ${ }^{21}$ Aj Polákovu inscenáciu dramaturgoval Martin Porubjak, uvádzala sa od roku 1993 do roku 2004 a Lasicov starnúci intelektuálny Cyrano sa zaradil k jeho životným hereckým výkonom. Tvorcovia v Činohre SND sa vrátili k pôvodnému názvu hry Cyrano z Bergeracu a rozhodli sa pre jazykovo aktualizovaný preklad Lubomíra Feldeka, pripravený v spolupráci s dcérou Annou. ${ }^{22}$ Reč postáv tak nadobudla súčasnejšiu podobu, vrátane množstva slangových a erotizujúcich výrazov. Ladislav Čavojský jazykové posuny sumarizoval slovami: „V preklade je rostandovská galantnost' na ústupe, poráža ju feldekovská drsnost’ a drzost'. “23 Pod-

${ }^{19}$ GRUSKOVÁ, A. Priestor a silueta. In Prednášky o divadle III. (Ed. Z. Pašuthová). Bratislava : Vysoká škola múzických umení, 2016, s. 156.

${ }^{20}$ SND angažovalo Bratislavský chlapčenský zbor.

${ }^{21}$ Inscenácia Cyrano vznikla v spolupráci Štúdia L+ S a Divadla ASTORKA Korzo '90.

${ }^{22}$ Prvým krokom k novému prekladu sa stala inscenácia Cyrano z roku 1993. Inscenátori vtedy podrobili Rostandov text kolektívnej autorskej úprave, iba klúčové výstupy boli prebásnené Lubomírom Feldekom.

${ }^{23}$ ČAVOJSKÝ, L. O nosisku nosatom, o Hubovi Hubatom. In Literárny (dvoj)týždenník, 2005, roč. 18, č. $13-14$, s. 3 . 


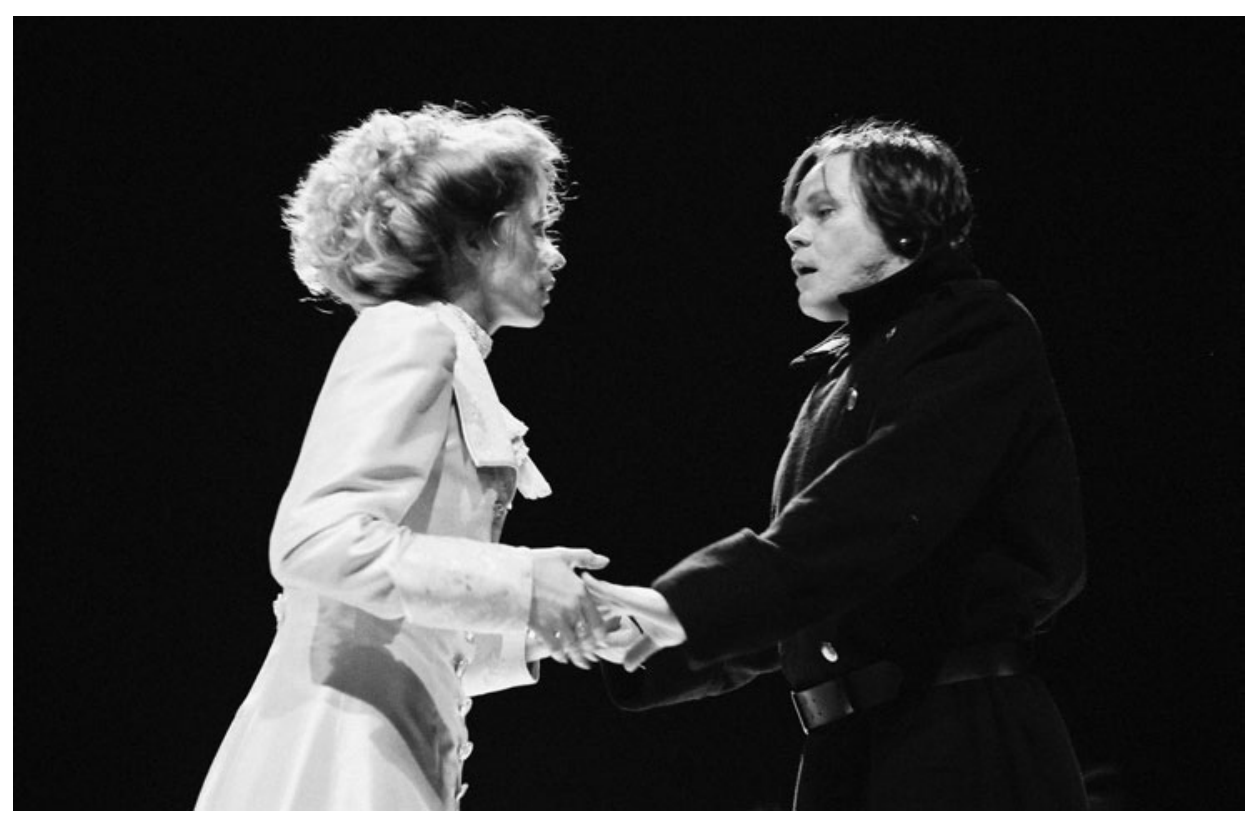

Edmond Rostand: Cyrano z Bergeracu. Činohra Slovenského národného divadla, premiéra 22. 1. 2005. Réžia Vladimír Morávek. Diana Mórová (Roxana), Robert Roth (Kristián). Foto archív SND. Snímka Jana Nemčoková.

l’a neho sa prekladatel' nepochybne vyhol jazykovej skostnatenosti a nude, ale „rečou urobil zo Cyrana uličníka" a Roxanin slovník oprostil od jemnosti preciózok. ${ }^{24}$ Vladimír Štefko však vyzdvihol Feldekove "zvučné, rytmicky svieže“ alexandríny, ktoré "dokazujú, že ani súčasný jazyk nič neuberie na vznešenosti neoromantickej hry“. ${ }^{25}$ Argumentoval vyznením „legendárnych replík či monológov (napr. o nose i v balade v súboji s Valvertom)“, ale aj viacerých situácií, ako napr. výstup herca Montfleuryho v Burgundskom paláci. ${ }^{26}$

Partnermi Hubovho Cyrana v lúbostnom trojuholníku sa stali Roxana v podaní Diany Mórovej (neskôr ju alternovala Táňa Pauhofová) a Kristián de Nevillette Roberta Rotha. Hlavnému hrdinovi nechýbal povestný vel'ký nos a jeho tajnej láske oslňujúci ženský pôvab. V prípade výbušného Kristiána nahrádzal autorom akcentovanú krásu mladícky šarm a temperament. Napriek aktualizovanému jazyku sa inscenátori rozhodli vyhnút priamemu zosúčasneniu postáv prostredníctvom kostýmov a scénografie. Rovnako odmietli inšpiráciu barokom a Francúzskom polovice 17. storočia. Výnimku tvoril iba herec Montfleury, jeho archaickú deklamačnú vyumelkovanost̉ v krátkom karikatúrnom výstupe bravúrne predstavil Jozef Vajda. Inscenátori si predstavovali „Cyrana ako noblesného intelektuála“ a po dohode s javiskovou výtvarníčkou „sa rozhodli urobit’ z neho Rostandovho súčasníka“. ${ }^{27}$

\footnotetext{
${ }^{24}$ Tamže.

${ }_{25}^{2}$ ŠTEFKO, V. Hrdinská nekomédia podl’a Rostanda. In Divadlo v medzičase, 2005, roč. 4, č. 1 - 2, s. 42.

${ }^{26}$ Tamže.

${ }^{27}$ GRUSKOVÁ, A. Priestor a silueta, s. 158.
} 


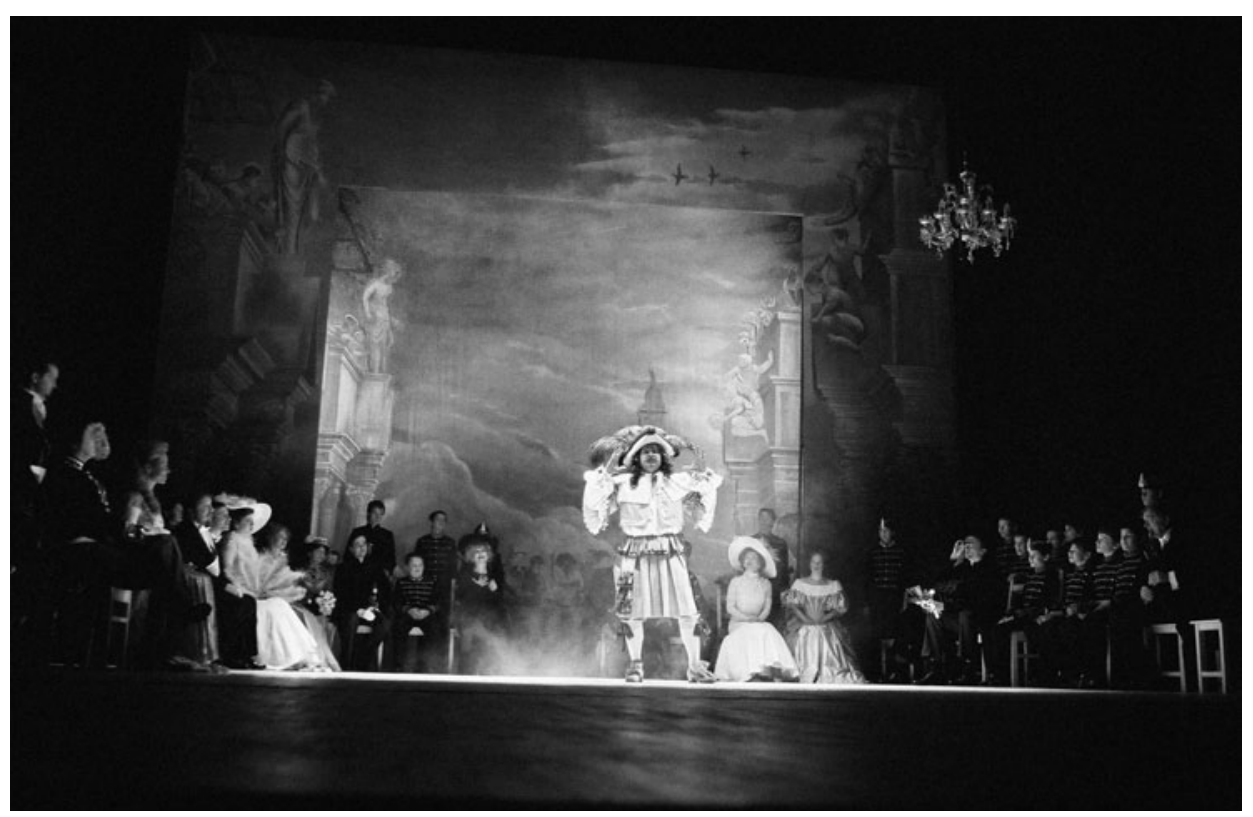

Edmond Rostand: Cyrano z Bergeracu. Činohra Slovenského národného divadla, premiéra 22. 1. 2005. Réžia Vladimír Morávek. Jozef Vajda (Montfleury). Foto archív SND. Snímka Jana Nemčoková.

Alexandra Grusková cez kostýmovú výpravu posunula dej na začiatok 20. storočia: „Striedmu, prevažne čiernu farebnost pánskych spoločenských odevov dopĺn̆ali krehké ženské siluety vo svetlých pastelových tónoch. Krása a harmónia dámskej secesnej siluety, zachytenej najmä v kostýmoch Roxany, vytvárala kontrast k jednoduchosti a strohosti pánskych uniforiem. Celú inscenáciu prepájali odtiene modrej farby. Od blankytného horizontu oblohy až po parížsku modrú na kostýmoch kadetov. “28 Princíp monumentálne vel'kých plošných dekorácií umožnil zdôraznit’ sošne aranžované l'udské siluety. Scénografia v prvom dejstve citovala Veroneseho monumentálnu mal'bu Svadba v Káne Galilejskej, obraz sa využil ako pozadie pre divadelnú sálu. Obsahoval aj nebo posiate oblakmi, tento výtvarný motív poslúžil ako inšpirácia pre nasledujúce dejstvá, kde však dochádzalo k zmene jeho farebnosti a tým pádom aj celkovej nálady (napr. jesenné oranžovo-hnedé tóny charakterizovali výstup v kláštore a evokovali ,jeseň života“). Premeny miesta deja, striedanie exteriérových a interiérových scén sa podarilo vyriešit vymedzením štvorcovej hracej plochy uprostred parketu javiska. Zmenou jej povrchu „na zelený trávnik, blato, bojisko alebo jesenný park zasypaný lístím“ ${ }^{29}$ a za pomoci osvetlenia v rôznych tónoch režisér spolu s výtvarníčkou účinne menili priestor aj atmosféru.

Vznikla pompézna inscenácia s množstvom prekrásnych živých obrazov, pôsobivých výstupov a kvalitného herectva. Mala dobrú divácku návštevnost', poistky však nevyrazila. Ani v dobrom, ani v zlom slova zmysle sa šok nekonal, provoka-

\footnotetext{
${ }^{28}$ Tamže.

${ }^{29}$ Tamže.
} 


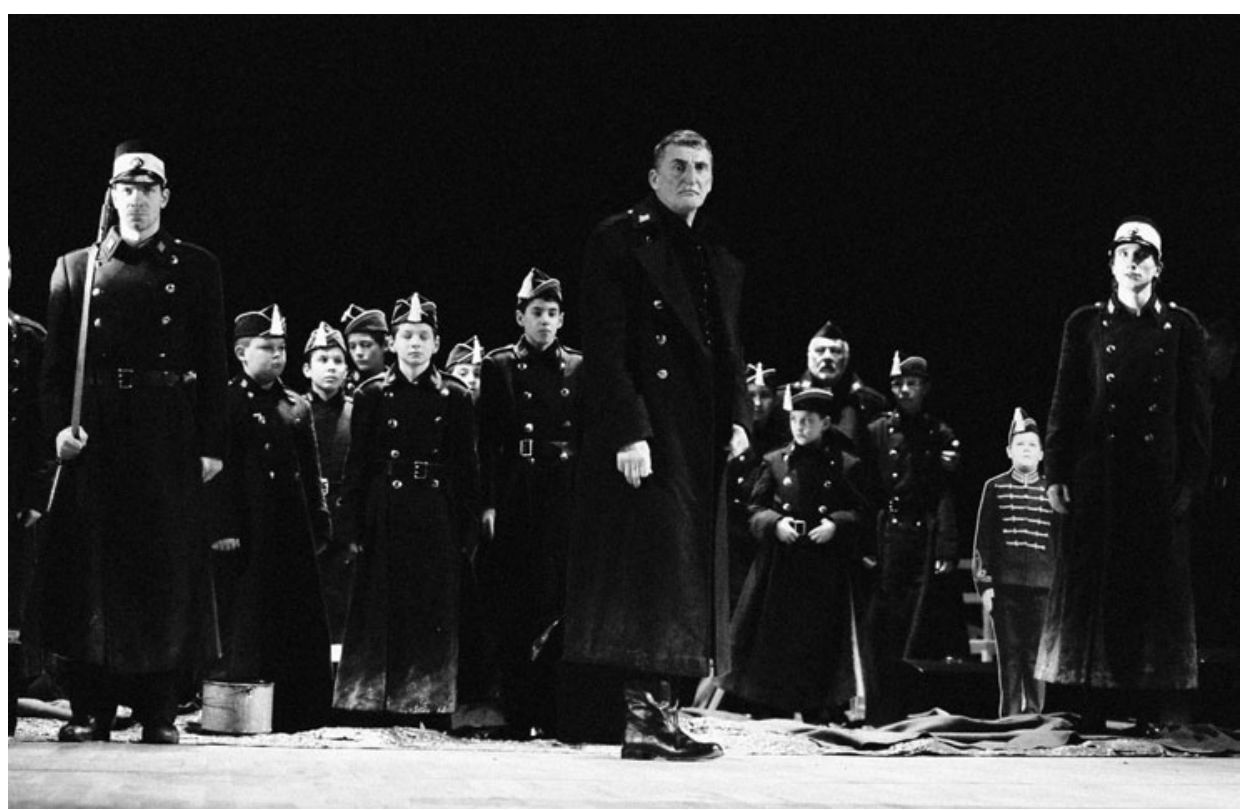

Edmond Rostand: Cyrano z Bergeracu. Činohra Slovenského národného divadla, premiéra 22. 1. 2005. Réžia Vladimír Morávek. Martin Huba (Cyrano) a kadeti. Foto archív SND. Snímka Jana Nemčoková.

tívny režisér k Rostandovej hre pristúpil s rešpektom a v konečnom výsledku zvolil pomerne konzervatívny prístup. Spolu s Martinom Porubjakom síce text upravovali a skracovali, ale verne sa držali príbehovej línie a dejových zvratov bez toho, aby sa dopustili interpretačných extravagancií. Vel'korysé mizanscény hru predovšetkým ilustrovali, ovel’a menej než v Macbethovi rozkrývali príbeh a jeho možné významy. Pravda, tvorcovia svoj výklad obohatili o subtílnu tému detinskosti a chlapčenstva, ktoré žijú v mužoch a ovplyvňujú ich skutky, či ide o bojovníkov, básnikov alebo temperamentných milencov. No túto líniu sa podarilo vykomunikovat iba čiastočne a viac v rovine protivojnového protestu - najmä v rámci štvrtého dejstva. Začínalo sa na svitaní v bojovom tábore gaskonských kadetov, ktorí v súlade s autorskými poznámkami spali zahalení do pláštov. V rámci ranného brieždenia bolo vidno iba siluety spiacich vojakov. Ked’ sa na javisku „rozvidnelo“, ukázalo sa, že čast’ spáčov boli malí chlapci v uniformách. Išlo o jeden z majstrovských, vizuálne i výpovedne silných Morávkových živých obrazov.

V recenziách Sone Šimkovej i Vladimíra Štefka zazneli slová uznania na margo zviditel'nenia obchádzaného motívu Rostandovej hry - myšlienky „o zbytočnom zabíjaní l’udí" ${ }^{\prime 30}$. Štefko vnímal detských kadetov ako „chlapiatka“, čo stoja ",ako výkričníky voči l’udskému chaosu, nemravnosti a jej vrcholnému produktu - vojne“. ${ }^{31}$ Šimková ich prítomnosť čítala tiež ako upozornenie "na to večne detské v človeku“, na „akýsi rudiment detskej duše“, spojený s pojmom hrdinstva a cti. „Detské postavičky

\footnotetext{
${ }^{30}$ ŠTEFKO, V. Hrdinská nekomédia podl’a Rostanda, s. 42.

${ }^{31}$ Tamže, s. $42-43$.
} 
v menších skupinkách, ba i jednotlivo vedie Morávek celou inscenáciou. Nastolujú detskú tému“" ktorá ",automaticky pomenúva to lepšie - večné detské - v človeku“, k čomu patrí „aj hravost’ a schopnost' hravej spolupráce“. ${ }^{32}$ Tento aspekt postrehla Šimková v interpretácii slávnej nočnej scény dvorenia, ktorú označila za najpôvabnejšiu pasáž inscenácie: „Tam si Cyrano a Kristián pod Roxaniným oknom bratsky vymieňajú miesta a napriek vekovému rozdielu obaja rovnako mladícky nadšene Roxane kurizujú. “33 Kritička si vari ako jediná všimla kontinuálne rozvíjanie témy pretrvávania chlapčenskosti v mužoch ako zdroja citlivosti a zranitel’nosti, ktorú však v staršom veku zväčša zatajujú a kamuflujú. „Ak na jednej strane detskost̉ má svoje pozitíva, detinskost’ sa už tak nevypláca. Čo ak Cyranovi práve detinský strach zabránil odkryt’ pravdu svojho citu skôr, než na smrtel'nej posteli, čím šancu získat’ kus pozemského štastia pre Roxanu i pre seba premárnil?“34

Dôležitost' tohto motívu potvrdzovali Morávkove slová v predpremiérovom rozhovore: „V̌̌dy som nakoniec zistil, že aj tie najvznešenejšie osudy sú iba príbehom detí. “35 Dôsledne ho vkomponoval do štruktúry inscenácie, zostal však málo čitatel'ný a v rámci interpretácie drámy l'úbostného trojuholníka Cyrano - Roxana - Kristián priam nenápadný. Zámer zostal nenaplnený, téma pretrvávajúcej detskej krehkosti a plachosti ovplyvňujúcej život človeka sa do výsledného javiskového tvaru vpečatila príliš slabo. Melodramatický príbeh tým pádom strácal hlbšiu výpovednú hodnotu, filozofický zmysel. Nadobúdal podobu kurióznej situácie (zvláštne, priam tragické spojenectvo sokov v láske), chýbala mu híbavost’. Zostal len divácky prít’ažlivý základný príbeh lásky a cti.

Diana Mórová ako Roxana, t. j. ženský stredobod lúbostnej zápletky, bezo zvyšku naplnila predstavu mimoriadne krásnej, šarmantnej, krehkej a zároveň koketnej bytosti, ktorá túži po vel'kej láske a často nechtiac zamotáva mužom hlavu. Pod Morávkovým režijným vedením zdisciplinovala svoj prejav, čo ocenili viacerí recenzenti. Robert Roth obišiel charakteristiku Rostandovho prostoduchého krásavca. Jeho Kristián mal mladícky horúcu hlavu, bola to osobnost', ktorej nechýbala odvaha a statočnost', len úprimný cit ju oberal o slová a vyvolával bezradnost'. Bojovnost a temperament nechýbali ani Cyranovi. V podaní Martina Hubu išlo jednoznačne o postaršieho outsidera, ktorý nie nosom, ale formátom osobnosti (aj výškou) prečnieval nad okolím, zameraným zväčša na sebastredné hmotné a pozemské radosti. Vladimír Štefko pedantne zaznamenal, že išlo už o deviateho slovenského Cyrana. Jeho predstavitel” neopakoval svojich úspešných predchodcov, nebol to ani „rytier luny bez bázne a hany" ako Karol Machata, ani zakomplexovaný muž, neschopný zabojovat’ o lásku a vyvažujúci svoj hendikep hrdinstvom a originálnymi kúskami - Igor Hrabinský, či "filozofujúci ironik“ typu Milana Lasicu. Podla Štefka „Huba obdaril (...) svojho hrdinu nervnostou, a láskou łažko ukrývanou. (...) Jeho Cyrano je v podstate utýraný človek, ktorý si zachováva v každej situácii čistý štít. “36 Inscenácia i herec sa snažili vyvarovat’ romantického oparu, ale aj irónie a grotesknos-

${ }^{32}$ ŠIMKOVÁ, S. Cyrano o detstve a detinskosti. „Panache blanche“. In Divadlo v medzičase, 2005, roč. 4, č. $1-2$, s. 45 .

${ }^{33}$ Tamže.

${ }^{34}$ Tamže.

${ }^{35}$ MORÁVEK, V. - JENČÍKOVÁ, M. V Bratislave chcem vyrazit poistky. Režisér Vladimír Morávek hádže po hercoch v národných divadlách avantgardou. [Rozhovor], s. IV.

36 STTEFKO, V. Hrdinská nekomédia podla Rostanda. s. 43. 


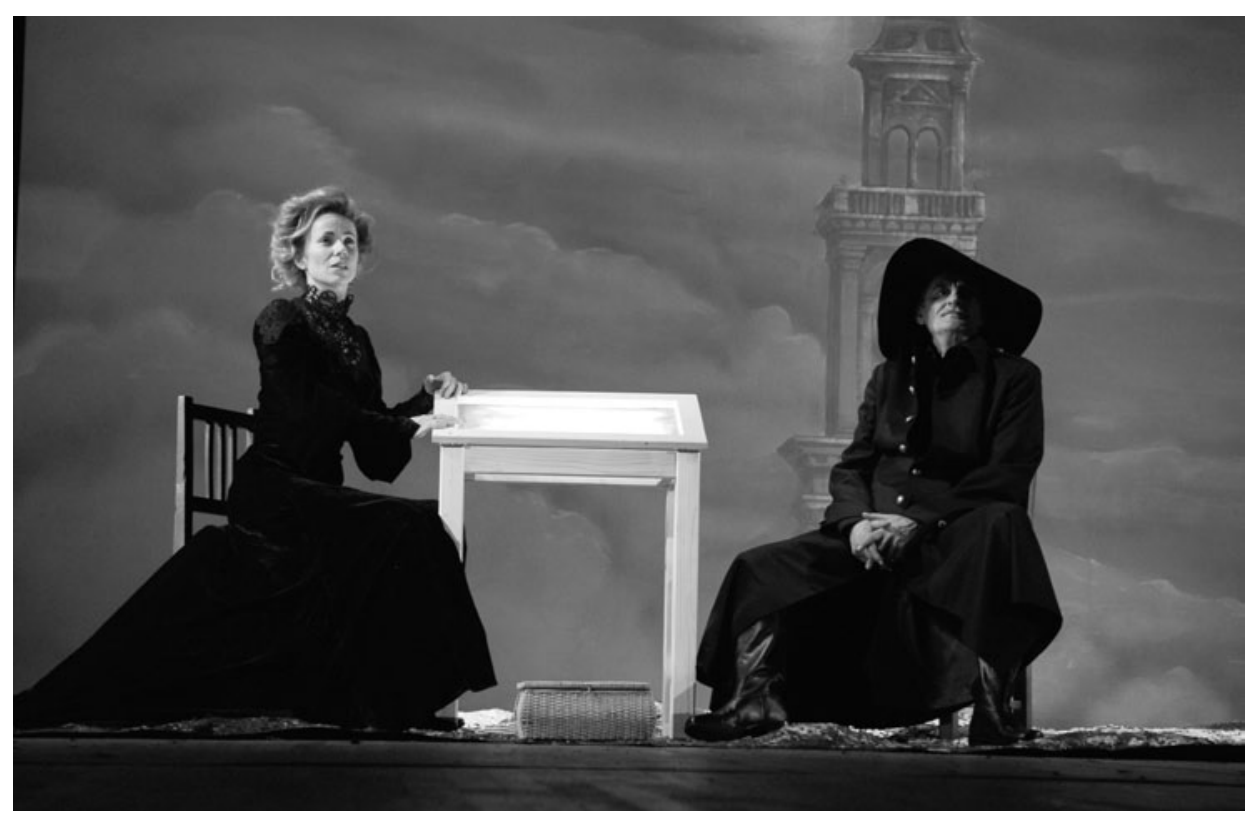

Edmond Rostand: Cyrano z Bergeracu. Činohra Slovenského národného divadla, premiéra 22. 1. 2005. Réžia Vladimír Morávek. Diana Mórová (Roxana), Martin Huba (Cyrano). Foto archív SND. Snímka Jana Nemčoková.

ti. Morávek posúval inscenáciu k väčšej vážnosti, temer k realistickej dráme, ktorú Štefko nazval až „drámou apelatívnou“37. Podobne čítal interpretáciu hry mladý kritik Daniel Uherek, videl v nej reakciu na súčasný svet, ktorý lásku vymenil „za bezhlavú zmyselnost"“, kde „kultivovanost’ prestala byt’ hodnotou. (...) Inscenácia Cyrana je dôkazom toho, že sme prestali byṫ schopní vnímat’ krásu, poéziu a prchavost' príjemných okamihov a zamerali sme sa na takzvané trvalé, hmotné hodnoty. Slovenské národné divadlo touto produkciou vážne obviňuje svet z necitlivosti a zatrpknutosti.“ ${ }^{38}$

Česká divadelná kritika bratislavského Cyrana z Bergeracu rázne odmietla. Josef Mlejnek svoje príkre hodnotenie vyjadril v samotnom názve recenzie: Padni komu padni - nedá sa režírovat l’avou zadnou. Inscenáciu označil za zdíhavú, vyznievajúcu ako „napoly sentimentálne operetná ryba, napoly muzikálový rak“ s niekol'kými dobrými, no nedotiahnutými nápadmi. ${ }^{39} \mathrm{Aj}$ šéfredaktor divadelného časopisu Svět a divadlo Karel Král vyčítal naštudovaniu „operno - operetnú teatrálnost" “40, opakovanie Morávkových režijných postupov, Hubových osvedčených hereckých polôh, gest a intonácií, Fikejzovej hudobnej ilustratívnosti. ${ }^{41}$ Odmietol záver, ktorý bol podla neho melodramatický, spochybnil prehnané množstvo stoličiek a dekoratívnych prv-

\footnotetext{
${ }^{37}$ Tamže, s. 42 .

${ }^{38}$ UHEREK, D. Cyrano - náš súčasník. In Slovo, 2005, roč. 7, č. 7, s. 15, 22. 2. 2005.

${ }^{39}$ MLEJNEK, J. Padni komu padni - nelze režírovat levou zadní. In Týdeník Rozhlas, 2005, roč. 15, č. 43 , s. 1.

${ }^{40}$ KRÁL, K. Drama z anatomie. In Svět a divadlo, 2005, roč. 16, č. 4, s. 50.

${ }^{41}$ Tamže, s. $46-52$.
} 
kov na javisku, vrátane železnej sochy koňa. Neprijal detských kadetov, otcovsko-synovský vzt’ah Cyrana s Kristiánom, priznal sa k antipatii voči hlavnému hrdinovi bratislavskej inscenácie atd’. Mlejnek ani Král neboli jediní českí kritici, ktorí sa vyslovili proti: problematické prijatie sa ušlo Morávkovmu Cyranovi z Bergeracu tiež na medzinárodnom festivale Divadlo 2005 v Plzni.

\section{Ohliadnutie sa - ex post}

Vladimír Morávek po roku 2005 viac na Slovensku nepracoval. V tom istom roku odišiel z Klicperovho divadla a vrátil sa do mesta svojich štúdií a režijných začiatkov - nastúpil do Divadla Husa na provázku v Brne.

Z dvoch slovenských inscenácií mala výraznejší vplyv na jeho profesionálny život nitrianska - cenami ovenčený Macbeth sa stal preňho významným medzníkom. Ako uviedol Zdeněk A. Tichý v prvej knižnej publikácii venovanej Morávkovej tvorbe: „V druhej polovici devätdesiatych rokov pracoval Vladimír Morávek tak trochu v tieni svojich kolegov Petra Lébla a Jana Antonína Pitínského. Jeho domovskú scénu v Hradci Králové síce kritika pasovala za divadlo roku 1998 a vzápätí aj roku 1999, ale prvé výrazné individuálne ocenenie získal v zahraničí - na Slovensku. " 42

Spolupráca so slovenskými divadelníkmi - mladým dramaturgom Svetozárom Sprušanským, javiskovou výtvarníčkou Alexandrou Gruskovou, hercom Mariánom Labudom a ústretovým kolektívom Divadla Andreja Bagara - Morávkovi jednoznačne prospela. Súbor ochotne a oddane plnil Morávkove požiadavky a napíñal nápady. Po čase si česká kritika uvedomila, že nitrianska shakespearovská inscenácia „sa nestala iba opulentnou hostinou smelých scénických vízií - už sa z nej dalo odčítat, že v tomto období Morávkov rukopis dozrieval a dostával ostrejšie kontúry. Nájdeme tu už prakticky všetko, čím tento režisér bude budit pozornost'." ${ }^{43}$

Dialóg Morávka s Gruskovou neskôr pokračoval v práci na niekol’kých d’alších projektoch. Sprušanský spoločnú inscenačnú skúsenost' pojal do svojej tvorivej výzbroje a postupne čoraz smelšie vystupoval v úlohe hlavného strojcu divadelného diela. Spolupráca s hostujúcimi i domácimi divadelníkmi mu poslúžila ako škola praktickej réžie. V prípade Mariána Labudu je na mieste domnievat’ sa, že macbethovská kapitola zohrala významnú úlohu v jeho tvorivej biografii, pripravila herca pre vari vrcholnú javiskovú kreáciu - stvárnenie kontroverznej postavy prezidenta vojnovej Slovenskej republiky Jozefa Tisa v dokumentárnej monodráme uvedenej v bratislavskom Divadle Aréna (2005, réžia Rastislav Ballek).

Morávkov výpravný Cyrano z Bergeracu obohatil slovenskú inscenačnú tradíciu slávnej Rostandovej hry a uviedol na javisko nový Feldekov preklad. Nestal sa inscenáciou roka ako Macbeth, ale podl’a konštatovania Sone Šimkovej nepochybne bol „,jednou z najlepších, ktoré v tejto sezóne [2004/2005 - pozn. N. L.] vznikli“44. Svoje interpretačné zámery režisér v Bratislave nenaplnil s takou mierou dôslednosti, aby sa stali čitatel’nými. Divácky oblúbený titul mal rozporuplné ohlasy. Na rozdiel od

${ }^{42}$ TICHÝ, Z. A. Jak Morávek potkal klasiky - anglické: Bůh ochraňuj toho zlobivého chlapce. In NĚMEČKOVÁ, L. - HULEC, V. - TICHÝ, Z.A. a kol. Vladimír Morávek. U nás nudou neumřete. (Ed. J. Dvořák), s. 111.

${ }^{43}$ Tamže, s. 114 .

${ }^{44}$ ŠIMKOVÁ, Soňa. Cyrano o detstve a detinskosti, s. 46. 
medzinárodne úspešnej nitrianskej inscenácie, bratislavskú naši najbližší západní susedia odmietli.

Jednoznačne sa preukázalo, že režisér dokáže lepšie zvládnut dobrý, zohratý a disciplinovaný kolektív vidieckeho divadla, ktoré sa ochotne podvolilo umeleckým aj časovým požiadavkám extravagantného tvorcu. Vniest' vrúcnost' kolektívneho tvorivého ducha do divadla hereckých individualít bolo preňho podstatne tažšie. Dané okolnosti sa odzrkadlili na výsledku, na jeho údernosti a sile. Potvrdzuje to aj svedectvo Morávkovej blízkej spolupracovníčky Alexandry Gruskovej, ktorá významne ovplyvnila výtvarnú podobu oboch inscenácií a dôverne poznala súbory DAB aj SND znútra: „Niektoré diela sa rodia l’ahko, iné t’ažšie. Často je to vec správneho načasovania či vhodnosti zaradenia titulu v súvislosti s momentálnou klímou v hereckom súbore. Pre činohru národného divadla to bola skúška jej kolektívneho ducha. Vždy ma mrzelo, že toto predstavenie súbor vnútorne neprijal, ale každý divadelný súbor je citlivý organizmus, ktorý si žije vlastným životom. ${ }^{\star 45}$

\section{TWO SLOVAK PRODUCTIONS BY VLADIMÍR MORÁVEK}

\section{Nadežda LINDOVSKÁ}

The Czech director Vladimír Morávek has staged two remarkable theatre productions in Slovakia. Both were staged on the verge of the millennia and were inspired by the world theatre classics. In 1999, Morávek staged Shakespeare's Macbeth at Andrej Bagar Theatre in Nitra, and in 2005, he directed Cyrano de Bergerac by Edmond Rostand on the stage of the Drama Company of the Slovak National Theatre in Bratislava. The production of Macbeth in Nitra was the most successful and most frequently awarded production of the 1998/1999 theatre season. Both national and international theatre critics were particularly generous in their reviews. The production of Cyrano de Bergerac in Bratislava was among the repertory titles most popular with the audiences. However, reviewers were more reserved in their opinions. Both the productions had several things in common, namely, they both strived to interpret the well-known drama text in a novel way, while putting emphasis on actors' performance, visuality and musicality. Morávek's directions of Macbeth and Cyrano have enriched the relations between the Czech and the Slovak theatre scenes with a new experience and have become a significant part of the art biographies of several theatre professionals.

Príspevok je súčastou riešenia projektu APVV č. 15-0764 Slovenské divadlo a súčasná európska divadelná kultúra - kontinuita a diskontinuita.

${ }^{45}$ GRUSKOVÁ, A. Priestor a silueta, s. 160. 


\title{
LITERATÚRA
}

ČAVOJSKÝ, Ladislav. O nosisku nosatom, o Hubovi Hubatom. In Literárny (dvoj)týždenník, 2005, roč. 18, č. $13-14$, s. 3, 11. ISSN 0862-5999.

ČAVOJSKÝ, Ladislav. Príbeh, prerozprávaný kreténom. In Literárny týždenník, 1999, roč. 12, č. 25, s. 11. ISSN 0862-5999.

GRUSKOVÁ, Alexandra. Priestor a silueta. In Prednášky o divadle III. (Ed. Zdenka Pašuthová). Bratislava : Vysoká škola múzických umení, 2016, s. 145 - 167. ISBN 978-80-89439-98-0.

GRUSKOVÁ, Alexandra - JANCUROVÁ, Helena. Obliekanie ilúzií. [Rozhovor]. In Pravda, 1999, č. 125, roč. 9, s. 11, 18. 5. 1999. ISSN 1335-4051.

HILSKÝ, Martin. Shakespeare a jeviště svět. Praha : Academia, 2010. 909 s. ISBN 978-80-200-1857-1.

JABORNÍK, Ján. Ó, Škótsko, Škótsko I. In Divadlo v medzičase, 1999, roč. 4, č. 2, s. 7. ISSN 13359355.

JABORNÍK, Ján. Ó, Škótsko, Škótsko II. In Divadlo v medzičase, 1999, roč. 4, č. 3 - 4, s. 6. ISSN 1335-9355.

KRÁL, Karel. Drama z anatomie. In Svět a divadlo, 2005, roč. 16, č. 4, s. 46 - 52. ISSN 0862-7258.

LINDOVSKÁ, Nadežda. Tragédia trpaslíka. In Javisko, 1999, roč. 31, č. 6, s. 6-7. ISSN 0323-2883.

LUKEŠ, Milan. Macbeth z domčeku. In Svět a divadlo, 2000, roč. 11, č. 3, s. 8 - 17. ISSN 0862-7258.

MLEJNEK, Jozef. Padni komu padni - nelze režírovat levou zadní. In Týdeník Rozhlas, 2005, roč. 15, č. 43, s. 1. ISSN 1213-2098.

MORÁVEK, Vladimír - JENČÍKOVÁ, Mária. V Bratislave chcem vyrazit poistky. Režisér Vladimír Morávek hádže po hercoch v národných divadlách avantgardou. [Rozhovor]. In Pravda, 2005, roč. 15, č. 17, príloha Sobota, s. I, IV, 22. 1. 2005. ISSN 1335-4051.

MORÁVEK, Vladimír - SPRUŚANSKÝ, Svetozár. Morávek o divadle. [Rozhovor]. In William Shakespeare: Macbeth [Bulletin k inscenácii]. Nitra : Divadlo Andreja Bagara, 1999, nečíslované.

NĚMEČKOVÁ, Lucie - HULEC, Vladimír - TICHÝ, Zdeněk A. a kol. Vladimír Morávek. U nás nudou neumřete. (Ed. Jan Dvořák). Praha : Pražská scéna, 2004. 312 s. ISBN 80-86102-20-3.

ŠIMKOVÁ, Soňa. Cyrano o detstve a detinskosti. „Panache blanche“. In Divadlo v medzičase, 2005, roč. 4, č. $1-2$, s. 45. ISSN 1335-9355.

ŠTEFKO, Vladimír. Hrdinská nekomédia podla Rostanda. In Divadlo v medzičase, 2005, roč. 4, č. $1-2$, s. $42-43$. ISSN 1335-9355.

UHEREK, Daniel. Cyrano - náš súčasník. In Slovo, 2005, roč. 7, č. 7, s. 15. ISSN 1335-7492.

\author{
Nadežda Lindovská \\ Ústav divadelnej a filmovej vedy CVU SAV \\ Dúbravská cesta 9 \\ 84104 Bratislava \\ e-mail: lindovska@vsmu.sk
}

